\title{
Plasticity, Political Economy, and Physical Growth Status of Guatemala Maya Children Living in the United States
}

\author{
BARRY BOGIN ${ }^{1 *}$ AND J AMES LOUCKY ${ }^{2}$ \\ 1 Department of Behavioral Sciences, University of Michigan-Dearborn, \\ Dearborn, Michigan 48128 \\ 2Department of Anthropol ogy, Western Washington University, Bellingham, \\ Washington 98225-9083
}

KEY WORDS migration; refugees; parental investment; life history theory

\begin{abstract}
Migration of Maya refugees to the United States since the late 1970s affords the opportunity to study the consequences of life in a new environment on the growth of Maya children. The children of this study live in Indiantown, Florida, and Los Angeles, California. Maya children between 4 and 14 years old $(n=240)$ were measured for height, weight, fatness, and muscularity. Overall, compared with reference data for the United States, the Maya children are, on average, healthy and well nourished. They are taller and heavier and carry more fat and muscle mass than Maya children living in a village in Guatemala. However, they are shorter, on average, than children of black, Mexican-American, and white ethnicity living in Indiantown. Children of Maya immigrants born in the United States tend to betaller than immigrant children born in Guatemala or Mexico. Families that invest economic and social resources in their children tend to have taller children. More economically successful families have taller children. Migration theory and political economy theory from the social sciences are combined with plasticity theory and life history theory (parental investment) from biology to interpret these data. Am J Phys Anthropol 102:17-32, 1997. @ 1997 Wiley-Liss, Inc.
\end{abstract}

The physical growth and development of children are sensitive indicators of the quality of the social, economic, and political environment in which they live (Fogel, 1986; Komlos, 1994; Schell, 1986; Tanner, 1981). In particular, child growth in terms of height, weight, and body composition (e.g., fatness and muscularity) are widely used indicators of nutritional status and health status for both individual child and the community. The reason that anthropometry serves as an index of environmental quality is that the development of the human phenotype is highly plastic. Plasticity refers to the ability of many organisms to change their biology or behavior during ontogeny to respond to changes in the environment, particularly when these are stressful. Plasticity is one of the three types of biological adaptations defined by Lasker (1969). The first and second types are "those genetically entrenched in the population by repeated natural selection and those dependent on a capacity to acclimatize in the short run" (Lasker, 1969:1484). Lasker characterizes the third type of adaptation as "modification of an individual during his growth and development ... the process is essentially irreversible after adulthood, ... and may be separately designated as plasticity" (Lasker, 1969: 1484). Due to a long developmental period before adulthood, human beings are, perhaps, the most plastic of all species and hence one of the most variable in terms of physical form and behavior.

\footnotetext{
Received 2 May 1995; Accepted 15August 1996.

*Correspondence to: Barry Bogin, Department of Behavioral Sciences, University of Michigan-Dearborn, Dearborn, MI 48128.
} 
This paper investigates the role that social, economic, and political variables play in the plasticity of human growth. The term political economy is sometimes associated with the doctrines of Karl Marx, but in fact there are many definitions. Political economy is defined here, following Leatherman and Goodman (this issue) and Orlove (1980), as the study of how people or groups of people living under conditions of constraint allocate scarce resources within their hierarchy of goals. Our topic examines how plasticity in the growth of Maya children reflects the political economy of Maya refugees living in the United States. The scarce resources include housing, education, employment, E nglish language, social and cultural knowledge of the United States, and money. The Maya must decide how to allocate those resources they command. Our focus is on how refugee Maya parents allocate resources to promote healthy development of their children.

\section{MATERIALS AND METHODS}

The Maya refugee children considered in this study reside in Indiantown, Florida (a rural community), and Los Angeles, California. A brief review of the history of Maya immigration into these two communities (Ashbranner and Conklin, 1986; Burns, 1989, 1993; Loucky, 1993, 1996; Bogin, 1995) provides a general description of the biocultural environment of the refugees of the present study.

Contemporary Maya of Guatemala are the cultural descendants of the complex civilization that occupied southern Mexico and Central America before the arrival of the Spanish in the early 1500s. Historically, Maya culture has been characterized by subsistence and market-oriented agriculture augmented by craft specialization, handwoven clothing, social behavior relating to household economy, endogamy, collective religious practice, use of the Maya calendar, and communication in a Maya language -22 of which are still in use in Guatemala. Some aspects of traditional Maya culture predate the Conquest; others are postcolonial syncretic blends. Many Maya believe that they have sangre de la raza, meaning blood of the pre-Conquest
Maya, running in their veins. These cultural traits continueto distinguish the Maya from the other major ethnic group in Guatemala, the Ladinos. In contrast to the Maya, Ladinos usually wear Western clothing, claim Spanish or other European ancestry, and practice social behavior derived largely from Spain or elsewhere in Europe. As of 1992, Guatemala's total population was 9,744,627, $61 \%$ of whom $(5,944,222)$ considered themsel ves to be ethnically Maya (Tzian, 1994).

Since the Conquest, the Maya have been socially, politically, and economically dominated, first by Spanish conquistadores and then by their Ladino cultural descendants (Adams, 1970; Handy, 1984; Smith, 1988; Warren, 1989). Forced labor recruitment persisted well into the twentieth century, and indigenous lands continue to be confiscated into the present day. Ladino peasants and the urban poor of Guatemala also suffered under both postcolonial and state regimes, and resistance by either Maya or Ladinos has been met with harsh military repression. During the late 1970s and early 1980s the social, economic, and political fates of Guatemala's Maya and poor Ladino population deteriorated further. One observer explains that during this time Guatemala experienced

a particularly bloody decade of civil war that has severely changed life there, especially for the Maya. ... The guerrilla insurgency and the overwhelming response by the military in Guatemala resulted in the destruction of hundreds of Maya towns and villages. The Maya of the mountainous area where the guerrilla forces found refuge were caught in an uprising that left them most vulnerable: they could not quickly leave their lands and villages like the insurgents and could not defend themselves against the weaponry of the state. As Beatriz Manz (1988) has documented, the destruction of the villages and societal structures in the area has been thorough (Burns 1989:21-22).

Tens of thousands of Maya were killed during the civil war, and more than 250,000 fled across the border into Mexico. Among the most numerous of those fleeing the country wereQ'anjob'al-speaking Maya from northwest Guatemala. The Mexican government disbanded many of the squalid refugee camps in the late 1980s. Thousands of Maya found their way to the U nited States, following earlier pioneers who arrived in the late 1970s and early 1980s. 
Despite the civil war and forced migration, most Maya living in the United States aspire to maintain cultural identity rooted in their formative experiences in rural Guatemala. Virtually all adult refugees were born in Guatemalan villages, speak a Maya language as their first tongue, and continue to express traditional Maya values in their observed behavior and during ethnographic interviews (Loucky, 1993; Burns, 1993). Maya refugee children, on the other hand, were born or raised in the United States, and most learn both English and Spanish simultaneously. While Maya values are still strongly emphasized at home (Loucky, 1993; Burns, 1993; Kohpahl, 1994; Wellmeier, 1994), children are acquiring non-Maya cultural values and behaviors on the streets and in the schools. In the larger refugee communities, such as in Florida and Los Angeles, Maya social organizations exist which sponsor traditional religi ous and secular fiestas and other events attended by whole families. Many of these events follow the tzolkin, the 260 day ceremonial cal ender of the pre-Colonial Maya. The tzolkin has taken on a type of pan-Maya status that unites the different Maya language groups of Guatemala and Mexico as well as the refugees in the United States and Canada (Alvarado, 1995).

The families of the Maya children measured for this study belong to the Q'anjob'al language group. Q'anjob'al speakers come from a relatively small region in the northwest Guatemala highlands. Indeed, most of the families in our sample come from one town and several smaller haml ets surrounding this town. Thus, the Indiantown, Florida, and Los Angel es Maya refugees are from the same ethnic and geographic origin in Guatemala.

The political status of the Maya in the US is heterogeneous and includes many who have applied for (and in some cases won) political asylum, others who have gained legal rights to work and residency under the I mmigration Reform and Control Act of 1986, and many who remain undocumented. In Florida, adult Maya work as day laborers in agriculture, landscaping, construction, child care, and other informal sector jobs. In Los Angeles, most Maya over the age of 15 toil for 50 or more hours a week doing low-wage manual sewing work in the sweatshops of the garment district (Loucky, 1993). A few Maya have established their own sewing contracting shops (fabricas) with five to 25 employees, including other Maya. A few are beginning to work as paraprofessionals (nurses aides) or as semiskilled workers (hairdresser, el ectronic technician). In both Indiantown and Los Angeles the Q'anjob'al Maya have organized voluntary support organizations that hel $p$ with resettlement, employment, and housing and also sponsor community religious and cultural events designed to promote Maya values and ethnic identity.

\section{Samples}

In both Florida and Los Angel es, virtually all children under age 15 attend school. In Indiantown, children of all ethnicities attending the two elementary schools were measured during February of 1992. Four ethnic groups-Maya, Mexican, white, blackprovided large enough samples for statistical analysis. Listed in Table 1 are sample sizes by age and ethnic group. There are too few 13- and 14-year-olds to compute descriptive statistics, so the age distribution was truncated at 12 years. The names of the ethnic groups used here reflect the selfreported names provided by the children of Indiantown or by their school teachers. The Los Angeles Maya children were measured at a Christmas party sponsored by a Maya cultural organization in December, 1992. A few children were measured in their homes. As in Florida, children were asked to selfidentify their ethnicity, or, in the case of the young children, adults familiar with the child were asked. Sample sizes are listed in Table 2.

\section{Measurement protocols}

All anthropometry was done by the biol ogical anthropologist on our team (B.B.) following standard procedures (Cameron, 1984). The measurements taken on each child are height, weight, arm circumference, and triceps skinfol d. In I ndiantown a teacher's aide or administration staff member familiar with the children recorded all the measurements and verified identification data. Chronologi- 
TABLE 1. Numbers of boys (B) and girls (G) measured in Indiantown in each ethnic group by age

\begin{tabular}{|c|c|c|c|c|c|c|c|c|}
\hline \multirow[b]{2}{*}{ Age } & \multicolumn{2}{|c|}{ Mayan } & \multicolumn{2}{|c|}{ Mexican } & \multicolumn{2}{|c|}{ White } & \multicolumn{2}{|c|}{ Black } \\
\hline & $B$ & $\bar{G}$ & $B$ & G & $B$ & $\bar{G}$ & $B$ & $\bar{G}$ \\
\hline 4 & 1 & 4 & 6 & 3 & 0 & 1 & 5 & 3 \\
\hline 5 & 8 & 9 & 17 & 8 & 11 & 4 & 11 & 14 \\
\hline 6 & 11 & 12 & 17 & 20 & 10 & 9 & 10 & 18 \\
\hline 7 & 7 & 8 & 17 & 16 & 11 & 11 & 9 & 21 \\
\hline 8 & 6 & 8 & 9 & 11 & 16 & 13 & 19 & 16 \\
\hline 9 & 5 & 5 & 16 & 10 & 14 & 8 & 11 & 16 \\
\hline 10 & 5 & 3 & 9 & 12 & 9 & 10 & 9 & 11 \\
\hline 11 & 6 & 4 & 3 & 3 & 0 & 0 & 4 & 2 \\
\hline 12 & 3 & 0 & 0 & 0 & 0 & 0 & 0 & 0 \\
\hline
\end{tabular}

TABLE 2. Numbers of Maya boys (B) and girls ( $G$ ) by age and sex for the Indiantown, Los Angeles, Guatemala 1979-1980, and Guatemala 1989-1990 samples

\begin{tabular}{|c|c|c|c|c|c|c|c|c|}
\hline \multirow[b]{2}{*}{ Age } & \multicolumn{2}{|c|}{$\begin{array}{l}\text { Indian- } \\
\text { town }\end{array}$} & \multicolumn{2}{|c|}{$\begin{array}{c}\text { Los } \\
\text { Angeles }\end{array}$} & \multicolumn{2}{|c|}{$\begin{array}{l}\text { Guatemala } \\
1979-1980\end{array}$} & \multicolumn{2}{|c|}{$\begin{array}{l}\text { Guatemala } \\
1989-1990\end{array}$} \\
\hline & $B$ & $\bar{G}$ & $B$ & $\bar{G}$ & B & $\mathrm{G}$ & B & $\mathrm{G}$ \\
\hline 4 & 1 & 4 & 7 & 8 & & & & \\
\hline 5 & 8 & 9 & 14 & 6 & 19 & 7 & 0 & 1 \\
\hline 6 & 11 & 12 & 7 & 9 & 1 & 5 & 15 & 19 \\
\hline 7 & 7 & 8 & 2 & 8 & 98 & 76 & 115 & 94 \\
\hline 8 & 6 & 8 & 7 & 2 & 6 & 6 & & 104 \\
\hline 9 & 5 & 5 & 12 & $\overline{6}$ & 59 & 49 & 104 & 103 \\
\hline 10 & 5 & 3 & 6 & 8 & 5 & 2 & 70 & 0 \\
\hline 11 & 6 & 4 & 6 & 9 & 49 & 2 & 3 & 35 \\
\hline 12 & 3 & 0 & 6 & 5 & 36 & 21 & 59 & 43 \\
\hline
\end{tabular}

cal age was ascertained from birth certificates or official school records. In Los Angeles children were measured in the presence of their father, mother, or both parents. The parents were asked to provide proof of their child's date of birth or were asked twice for the birth date. The place of birth of the parents and the child and the length of the child's residence in the United States were al so collected. Several members of the Maya community assisted with the gathering of this information. In-take data and the anthropometric measurements were recorded and verified by the coauthor of this paper (J.L.), an applied anthropologist who has been working with the Los Angeles Maya community since 1985 .

The rationale for each of these measurements is as follows. Since height increases over time, it is an indicator of the history of nutritional status and health of a child. In contrast, weight can both increase and decrease over timeand, ther efore, relates more to recent nutrition and health status (Waterlow et al., 1977). Circumferences and skin- folds are generally accepted measures for body composition (i.e., lean body mass and fat mass). Body composition is often used as a proxy for nutritional status. Lean body mass is an indicator for the body's reserves of protein, and fat mass is an indicator of the body's reserves of energy (Martorell et al., 1976; F risancho, 1981). In the present study, arm circumference and triceps skinfold were used to calculate fat area and muscle area at the midpoint of the arm (Gurney and J elliffe, 1973). These calculated areas have been shown to correlate more closely with fat and lean body mass than the raw circumferences and diameters (F risancho, 1990).

In order to compare the growth of Maya living in the United States with Maya living in their homeland, two samples of Guatemala-resident Maya are included in the analysis. The Guatemalan Maya aresamples of children attending a public school in a traditional Maya town located in the Kaqchikel language region, about $150 \mathrm{~km}$ southeast of the Q'anjob'al town. Previous analysis, however, shows that the Kaqchikel school children are representative in height, weight, and other physical dimensions of Maya children in Guatemala of very low socioeconomic status (SES) who suffer chronic mild-to-moderate undernutrition (Méndez and Behrhorst, 1963; Bogin and MacVean, 1984; Bogin et al., 1992). The first sample consists of 669 boys and girls measured in 1979 and 1980. The second sample is of 995 boys and girls measured in 1989 and 1990. Samples sizes by age and sex are given in Table 2.

\section{RESULTS}

For analysis the data for girls and boys and the data for the Indiantown and Los Angeles samples were combined. These procedures are justified by multiple regression analysis of the effects of the independent variables, age, sample (Indiantown, Los Angeles, or Guatemala), and sex, on each of the growth measurements (dependent variables), with a significance level set at $\mathrm{P}=$ 0.01 . Sex does not have a significant effect on height, weight, arm circumference, triceps skinfold, or fat area but does have a significant effect on muscle area; boys have more muscle. A difference in muscularity between 
boys and girls is found in most populations, and, although statistically significant, it is small prior to puberty. Since all the samples show the same magnitude of difference (i.e., no statistical interaction), combining data for boys and girls within groups does not change the effect of age or sample on the growth data.

The multiple regression analysis revealed no significant differences between the Indiantown and Los Angeles samples of Maya children for any of the anthropometric variables. The combined samples are referred to below as the LA-IT sample. Merging the data by sex and sample in this manner increases sample sizes, thus increasing the power of the statistical tests.

\section{Growth status of United States vs. Guatemalan Maya}

The mean values for height and weight at each age for LA-IT sample and the two samples from Guatemala (GUATE) are presented in Figure 1. There are no significant differences between the means of the older and more recent GUATE samples. TheLA-IT sample is significantly larger than the two GUATE samples at virtually every age. The average difference across all ages between LA-IT and GUATE samples is $5.5 \mathrm{~cm}$ for height and $4.7 \mathrm{~kg}$ for weight. Significant differences are also found for comparisons of body composition; the LA-IT children have larger arm fat area (mean difference $=722.31 \mathrm{~mm}^{2}$ ) and muscle area (mean difference $=280 \mathrm{~mm}^{2}$ ) than either of the GUATE samples.

\section{Growth status of the Maya compared with other ethnic groups living in Indiantown}

The mean values by age and ethnicity for each of the growth variables are presented in Figures 2 and 3. For height (Fig. 2), analysis of variance with Scheffé post-hoc contrasts of means shows that the Maya ethnic group is significantly shorter than each of the other ethnic groups of Indiantown. Mexican-Americans are shorter than blacks or whites, but there is no statistical difference between blacks and whites. Mean values of height for a national sample of United States children (Hamill et al., 1977) are included in the comparisons for height.
The white and black samples of Indiantown equal or exceed the mean height of the national sample. Mexican-Americans are at or below the mean height of the national sample. This is true for each of the other anthropometric variables as well.

The Maya, as a group, weigh significantly less than whites or blacks. There is no significant difference between Maya and Mexican-Americans, nor are there differences between the white and black ethnic groups. There are no ethnic differences in body composition measures, such as for arm fat area or for arm muscle area (Fig. 3).

\section{Factors associated with the growth of the Los Angeles sample}

In this section the analysis focuses on differences in growth in height of the children within the Los Angeles sample of Maya children. For this sample we have information for place of birth of the parents and for the child and the length of time the child has lived in the United States. Figure 4 illustrates the distribution of height by age for all of the children in this sample. Imposed on the distribution are the linear regression and its $95 \%$ confidence limit lines.

All of the Maya parents were born in Guatemala. Their children in the sample were born in three countries: Guatemala, Mexico, and the United States. The effect of child birthplace is estimated by forming two groups, those born in the United States and those born elsewhere. A multiple regression analysis of height on birthplace and length of time in the US for the entire sample, after removing the effect of age, is not significant $(P=0.21$ for birthplace; $P=0.61$ for length of residence). A birthplace effect may be noted if the analysis is restricted to the cases that lie outside the confidence interval. Of the 51 children above the confidence interval, 30 were born in the US and 21 elsewhere. Of the 50 children below the confidence interval, 21 were born in the US and 29 in Mexico or Guatemala. A chi-square test, assuming an equal number of children in all cells, shows that birthplace is a significant effect at $P=0.07$. We interpret this result as a tendency for US-born Maya refugees to be taller than those born in Guatemala or Mexico. 

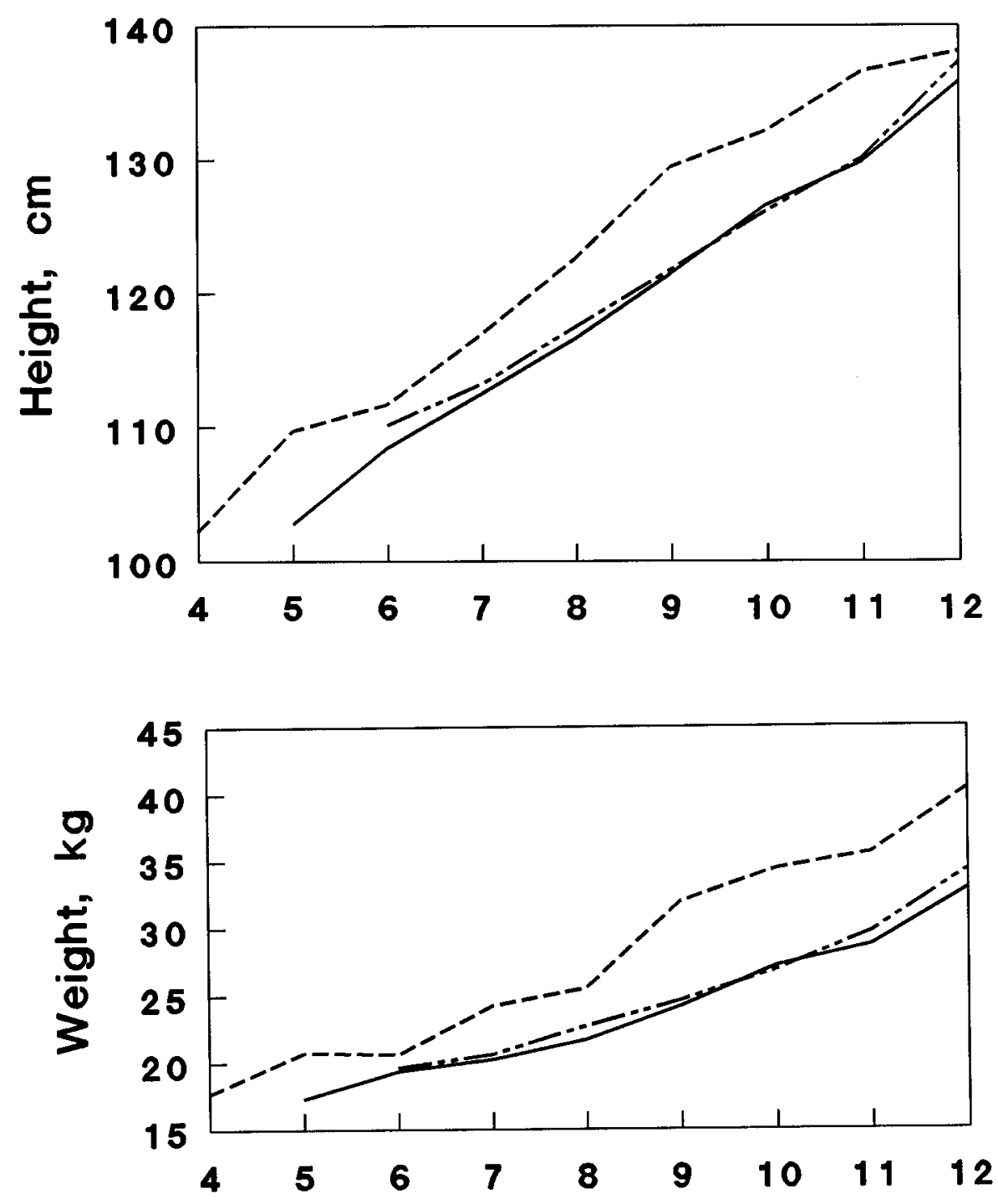

Age, years

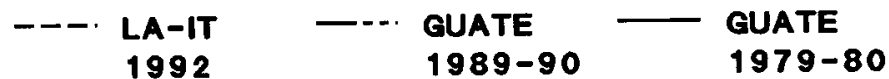

Fig. 1. Distribution of the mean height or weight by age of the Los Angeles and Indiantown Maya sample (LA-IT) and the Maya samples from Guatemala measured in 1979-1980 and 1989-1990 (GUATE). Data for boys and girls within samples are combined.

The bold symbols in Fig. 4 indicate individual children for whom we have some family ethnographic data. The authors visited these families in their homes and gained some understanding about their life in Gua- temala, decisions to migrate to the United States, and life in the United States. While we do not have enough ethnographic data for formal statistical analysis, we present some information about these children and 

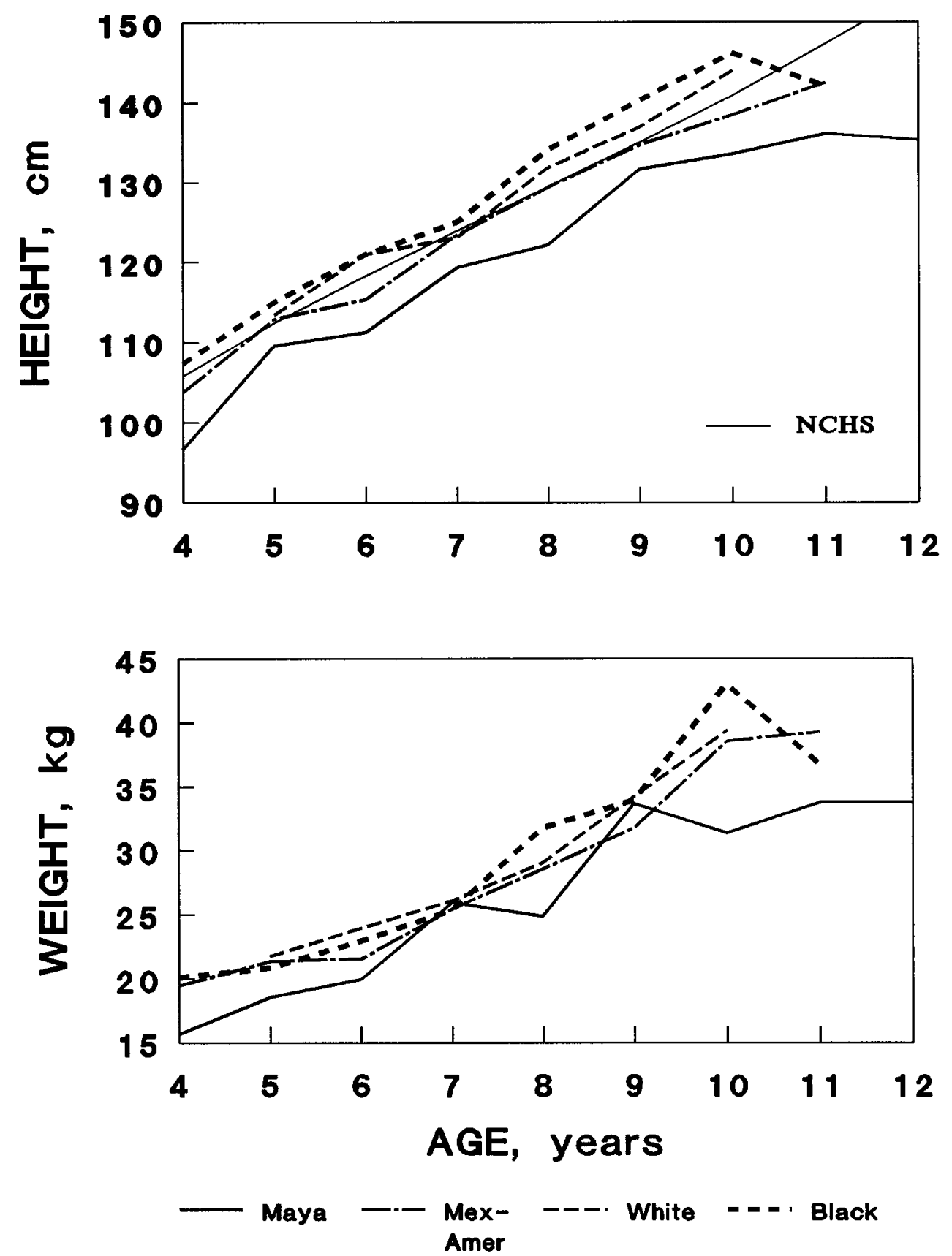

Fig. 2. Mean height or weight of Indiantown children by ethnic group and age. The height figure includes the median values for US children from an NCHS survey.

their families as a first step toward a more detailed biological and ethnographic (i.e., biocultural) analysis.

The upward solid triangle ( $\boldsymbol{\Delta}$ ) symbol (Fig. 4) represents children from the $M$ family, which has resided in the United States for about 3 years but has not made a successful adaptation to life in Los Angeles. They are very poor, even in comparison with other Maya in the community. The four older 

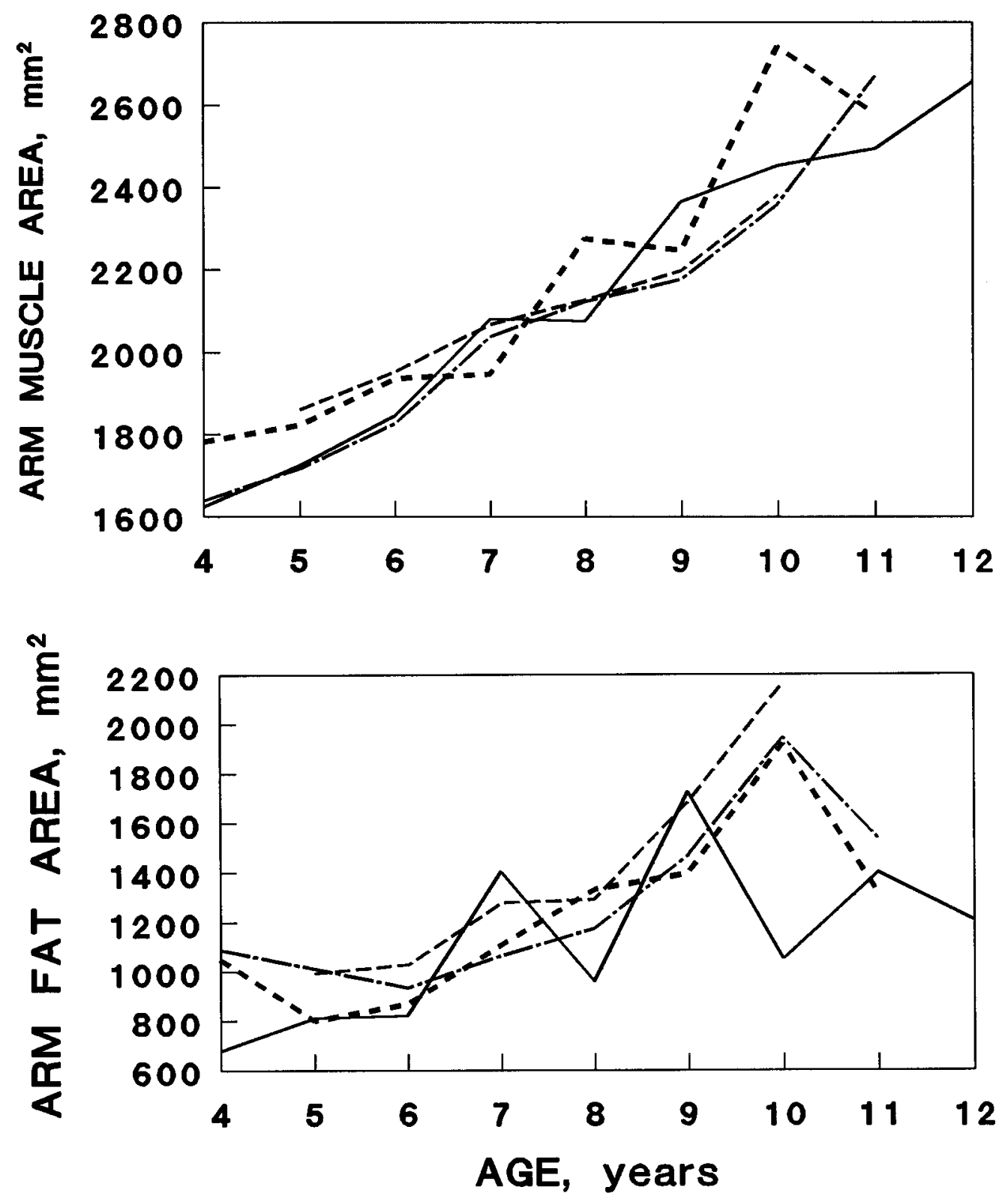

Maya --- Mex- ---. White ---' Black

Fig. 3. Mean arm muscle area or arm fat area of I ndiantown children by ethnic group and age.

M children were born in Guatemala, but the youngest child was born in a refugee camp in Mexico. The three oldest children are of average height; the two youngest are at or bel ow the lower confidence limit. The oldest
M daughter (age 10.5 years) does not attend school; rather, she stays home to care for the younger children whilethe parents areworking. The two Maya men with whom we visited this home commented that it was a 


\section{Los Angeles Maya Sample}

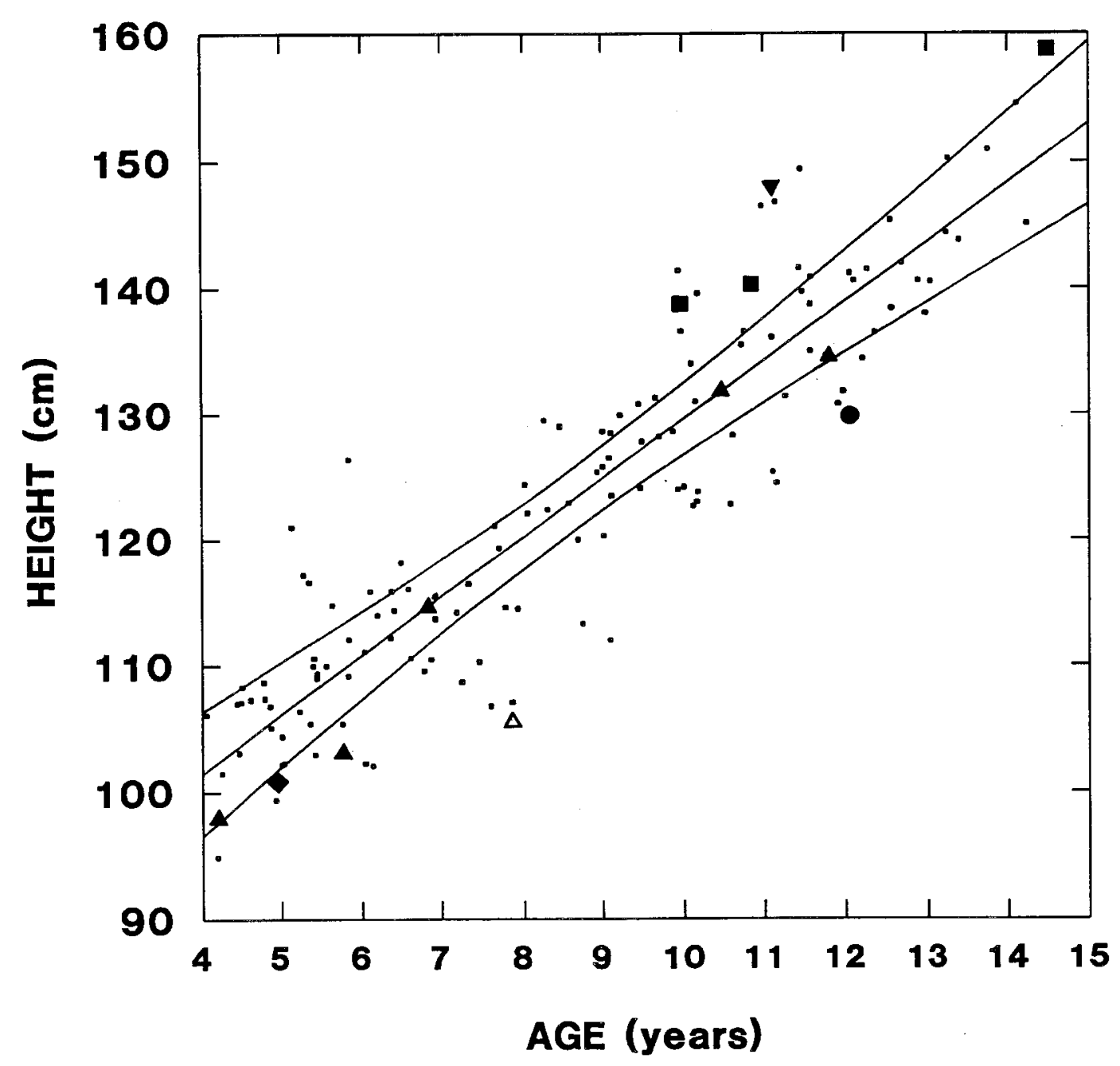

Fig. 4. Distribution of height by age for the Los Angeles sample Maya children. Lines represent the linear regression and $95 \%$ confidence interval. Symbols indicate children from families described in the text.

shame that the girl does not go to school. The parents could not speak English, or much Spanish, and were having difficulty finding work. A few weeks after our visit this family left Los Angeles to look for work elsewhere.

The $M$ children were measured in the family's apartment, which they share with the $T$ family. The $T$ family has been in Los Angeles longer than the $M$ family and is in fact supporting the $M$ family. The open triangle $(\triangle)$ symbol (Fig. 4) points to the datum for height of theyoungest daughter of the $T$ family. She was born in Los Angeles but is the shortest girl for her age group in the entire sample. The variation in stature of children from these two families shows that neither migration to the US nor birth in Los Angeles automatically results in taller stature. 
The solid circle (O) symbol (Fig. 4) is for a boy who was born in Los Angeles but returned to Guatemala when he was 1 year old. He lived there with his mother until he was 11 years old, at which time the family migrated back to Los Angeles. At age 12 years, he is about $10 \mathrm{~cm}$ shorter than the average child of the Los Angel es sample and about $5 \mathrm{~cm}$ shorter than boys his age of the Guatemala village sample. We were not told in detail why this boy traveled back to Guatemala, but we were informed that the family is very poor and that the boy and his mother needed support from their Guatemalan relatives.

The solid square ( $\square$ ) symbol (Fig. 4) denotes the children of two sisters who have made successful social and economic adjustments to life in the Los Angeles area. One sister trained as a nurse and works as a health paraprofessional. Her husband is a skilled tailor working in the garment industry and earns more than double the official mi nimum hourly wage. The other sister is a beautician and works in an upscale shop. Both families rent their own apartments in a middle-class suburb of Los Angeles. The parents say they moved from South-Central Los Angeles to these more expensive neighborhoods in order to protect and educate their children in better schools. The parents are of average height for Maya raised in Guatemala. Two of the children are siblings who were born in Guatemala, the 10- and 14-year-ol ds. The 11-year-old is a cousin who was born in Los Angel es. The above average growth of these children may reflect the soci oeconomic success of these families, combined with the investment the parents make in their offspring.

Higher SES alone is no guarantee of taller stature. The solid diamond ( $\bullet$ ) symbol (Fig. 4) indicates a boy from a family that has lived in South-Central Los Angeles since 1981. The father of this family is economically successful. He owns a garment-manufacturing shop and has contracts to make jeans for a major wholesaler. Before leaving Guatemala the father was a butcher and a community leader. In rural Guatemala this means that he devoted considerable time and money to sponsor fiestas and other community events. He continues this prac- tice in Los Angeles and maintains his community-leadership role. Our impression from visiting this family's home and talking with the father is that the family is very traditional in terms of many Maya values and behavior. Surprisingly, however, there was little mention of investment in his children in terms of education or their future. Wealso found during our visit that the parents of $\bullet$ are of shorter stature than average for Maya adults. Given the data we have, it is impossible to decide if the shorter than average stature of this boy is only a genetic trait or if thestyle of parental investment al so contributes.

The downward solid triangle $(\boldsymbol{\nabla})$ symbol (Fig. 4) is for a girl from another family that has a leadership role in the Maya community. The parents have only primary-school educations and work as semiskilled laborers in the garment industry. They are shorter in stature than the parents of the child discussed in the previous paragraph. However, they invest much of their resources into their children, who are expected to finish high school and go on to postsecondary education. The father of this family told us that

What is in the future depends on what my children do. Here the children will stay, eat well, live better than in Guatemala. But many adults are returning to Guatemala, because children here abandon their parents. So, it depends on your children here. If you have good work, and children study well, and you earn well, it is possible to rent or even buy a good house and not have to think about returning to Guatemala.

In further conversation this man explained that the investments he makes in his children will pay off for him when he is old and needs his children's support. At present, the above average height of this girl may well be a consequence of her parents' investments.

\section{DISCUSSION}

In addition to cultural traits, such as language and religious practice, physical features have also been used to define the Maya. One such feature is stature; Maya are often considered to be a short-stature people. While it is truethat the present-day Maya of Guatemala are, on average, shorter than Ladinos (Bogin and MacVean, 1984), the 
reasons for this height difference are a matter of some dispute. During fieldwork in Guatemala, the present authors often were told that Maya are "naturally" shorter than Ladinos. Naturally means that living Maya inherited their limited capacity for growth from their pre-Colombian ancestors. University-educated Ladinos, and occasionally even Maya men and women, expressed this view. Thus, genetics is the popular culture explanation for Maya short stature, a view also expressed by some foreign scientists and writers. One writer of popular science calls the Maya a "pygmy" people of the Americas: "several unrelated peoples... evolved small size independently [including the central African Pygmies] ... Bushman of southern Africa ... the Maya and other small-sized American I ndians who are arbitrarily classified as Pygmies because their adult men measure under 4 feet 11 inches" (Diamond, 1992:73). In the past, some serious scholars proposed that short-stature people, such as the Maya, are small but healthy (e.g., several chapters in Watts et al., 1975; Seckler, 1980, 1982; Roberts, 1985). Small here means short stature, due to either a genetic adaptation or an individual accommodation to an environment of poor nutrition. The but healthy means that the short stature does not compromise health, decrease physical or mental performance, or increase the risk of mortality.

The popular-culture, and popular-science, explanations of Maya stature are incorrect. Growth surveys show that the Maya are not "pygmies."By definition, pygmies are biological populations in which men average less than $150 \mathrm{~cm}$ tall as adults. Maya men average $156 \mathrm{~cm}$ to $169 \mathrm{~cm}$ tall in the few studies that have been published (Shattuck and Benedict, 1931; Steggerda and Benedict, 1932; Crile and Quiring, 1939; Goff, 1948; Méndez and Behrhorst, 1963; Bogin et al., 1992). A genetic limitation on growth in height also does not exist, as shown in the present study. Within the same generation, Maya children growing up in the United States average $5.5 \mathrm{~cm}$ taller than their age mates living in Guatemala. Selective migration (i.e., only the taller Maya choose to emigrate from Guatemala) cannot account for the results. Civil war in Guatemala forced entire villages of Maya to flee to Mexico and then to the US. Moreover, re views of research on selective migration find little or no evidence for selection according to phenotypic biological features (Bogin, 1988b; Lasker, 1995).

All of the "small-but-healthy" researchers have either repudiated their earlier views or had them repudiated by others. Today, the consensus of research is that physical growth and development are sensitive indicators of thequality of the social, economic, and political (SEP) environment. In this view, the short stature of a population is a proxy for an ecology for human development that results in nutritional deficiency, excessive energy expenditure, and poor health. Growth faltering during childhood is a plastic response in that it results in permanent short stature in adulthood. The SEP research also links deficits in growth with impairment in terms of physical work capacity (Spurr, 1983; Martorell, 1989; Ulijaszek and Strickland, 1993) and cognitive skills (Pelto and Pelto, 1989; Brown and Pollitt, 1996) and increased risk for morbidity and mortality (Pellietier, 1991).

Plasticity theory and the SEP view of growth determination seem to explain the difference between the growth of Maya children in Guatemala and in the United States. The migration of Maya refugees to the US breaks the cycle of poverty into which most Guatemalan Maya are born. The political economy of Guatemala creates an ecology for human development that deprives most Maya and Ladinos of sufficient food, health care, safe drinking water, education, and other basic needs. The situation is especially acute in the Maya cultural region of highland Guatemala. Long-standing political and economic policy of land appropriation and disinvestment in the economy of this region results in the highest levels of infant mortality, malnutrition, and growth faltering for all of Guatemala (Bossert and Peralta, 1987). In the United States, Maya children and their families are still of very low economic status. Those who are undocumented must live at the margins of US society. Nevertheless, the political economy of the United States offers economic, nutritional, educational, and public-health benefits unavail- 
able to most Maya in Guatemala, as well as lifewithout the threat of violencefrom insurgent or government military forces.

The LA-IT sample is, on average, taller than any sample of Guatemalan Maya and taller than many samples of low socioeconomic status Ladinos of Guatemala (Méndez and Behrhorst, 1963; Bogin and MacVean, 1984; Bogin et al., 1989; J ohnston et al., 1985; Plattner, 1974). However, the LA-IT sample is significantly shorter than the other ethnic groups of Indiantown. The body composition of the LA-IT Maya sample is, on average, similar to that of the other ethnic groups measured in Indiantown, who are similar in height, weight, and body composition to national samples of children from the same ethnic groups published by the National Center for Health Statistics (NCHS) (Hamill et al., 1977; J ohnson et al., 1981; Najjar and Kuczmarski, 1989). In terms of energy (fat) and protein (muscle) stores the LA-IT sample of Maya children appear to be generally healthy and well nourished. Why then are they shorter than the other ethnic groups?

These results show that the plasticity of human phenotypes changes at different rates for different traits. The present generation of Maya refugee children is likely to be in the first stage of a process of increasing stature from generation to generation. This process, known as the secular trend in growth, is often associated with migration from a low SES to a higher SES environment or in situ socioeconomic improvement (Garn, 1987; Bogin, 1988a). Classic examples of the secular trend in the growth of migrant children (Boas, 1912, 1940; Shapiro, 1939; Goldstein, 1943; Lasker, 1952) and more recent follow-up studies of these same populations show that over time the growth in height of each generation of the children of migrants continues to increase (Roche, 1979) until it converges on that of the host population.

Data for generations of Maya children and adults living in Guatemala show no evidence for a secular increase in stature (Bogin and MacVean, 1984). The comparison of the two GUATE samples shown in Figure 1 illustrates the lack of secular increase even in the most recent data available. A worldwide review of growth data from the twenti- eth century for succeeding generations of people living under low SES conditions and under political repression (e.g., South Africa prior to and during apartheid) finds either no secular increase in stature or negative secular change (Tobias, 1985). This is further evidence that the growth of populations of children is a sensitive indicator of the social, economic, and political environment.

In most studies that find a positive secular trend, the increase in mean height from generation to generation lags behind increases in weight and body composition. This happens because, as explained earlier, height reflects health and nutritional history, whereas weight and body composition reflect recent events. I ndeed, a child's hei ght is a historical record of both the individual and his or her parents. This is due to crossgenerational effects of chronic undernutrition and disease. These insults during the childhood of one generation are known to reduce the growth of the next generation of offspring (Van Wieringen, 1986). Conversely, children who are better nourished and healthier will give their own offspring a healthier prenatal start in life. Certainly, bigger mothers have longer, heavier babies who grow up to be taller children and adults (Garn et al., 1984). One example of this phenomenon comes from Mexican immigrants to the United States who have gotten taller, on average, with each generation since the 1930s (Bogin, 1989). The most recent generation of US-born MexicanAmericans (under 12 years old) has mean heights equal to NCHS references (Martorell et al., 1984). The Mexican-American samplefrom I ndiantown includes both immigrant and US-born children and, as predicted by the SEP explanation for the secular trend, are intermediate in stature between the black and white samples and the Maya sample.

\section{Family strategies for child survival and successful development}

Children are dependent on ol der individuals, usually their parents, for survival (Bogin, 1988a, 1990). The Maya parents of the samples of children analyzed here made the decision to migrate to the US rather than stay in Mexico or return to Guatemala. 
Those decisions are based on both biological criteria (food availability, disease, mortality) and SEP criteria (warfare, economic conditions, death threats). Given the biosocial nature of reasons for migrating, a combination of theory and analysis from social science and biological science is needed to understand the behavior of Maya parents. Migration theories from the social sciences emphasize that socioeconomic and political conditions are correl ates of decisions to relocate (Ravenstein, 1885; J ackson, 1969; Downing, 1979). Often these correlates are described as push or pull factors. Certainly, the civil war in Guatemala, destruction of Maya villages, dismal economic conditions before the war, and a period of hyperinflation and economic stagnation following the war were powerful push factors out of Guatemala. The potential for a better life in "EI Norte" (the United States) was an equally powerful pull factor.

The act of migration to the United States, however, is al so based upon parental investment decisions. In biology, the study of parental investment decisions is guided by life history theory (Stearns, 1992), centered on decisions regarding when to begin reproducing, how many offspring to have, how often to reproduce (i.e., birth spacing), and how much to invest in each offspring. In both Guatemala and the United States, Maya parents say that children raised in the United States are more likely to survive, grow better, and be healthier than children raised in Guatemala. In I ndiantown, women state that their infants and children are nearly twice the size they would be if raised in Guatemala. The mothers of Indiantown often ascribe the effect to the infant formulas they use (Stebor, 1992). One mother explains,

My daughter, Rosita, is 4 years old and is very small. I think she will be small all her life because she was so sick in Guatemala when she was a baby. She still doesn't eat well. Now look at my son who is almost a year old [born in the US]. Already heis walking, which means his legs are very strong. He is twice the size of Rosita when shewas a baby. I tell you, the difference is milk [formula] (Stebor, 1992:106).

Maya women, both those pregnant and those with infants, receive free or low cost health care and nutritional supplements from the WIC (Women, Infants, and Children) program. Stebor reports that Maya women acknowledge the value of the WIC program and justify the investment of time and money (lost wages) required to enroll in the program by pointing to their bigger, healthier babies and children. Infants in Florida are fed more total food, including some breast-feeding al ong with formula feeding. Maya mothers generally follow hygienic practices when preparing and storing formula, and safe drinking water is used to mix the formula. Thus, more than the use of formula alone explains improved growth of the refugee children. In contrast, prenatal and postnatal infant medical care and safe drinking water are usually not available in rural Guatemala. Dueto chronicundernutrition for the rural poor in Guatemala, Maya women may not produce a sufficient quantity of breast milk, and infant formulas are too expensive for most Maya to purchase.

When Maya women make note of the increased survival and improved growth of their children in the United States, they are expressing themselves in terms of parental investment theory. LeVine (1977) proposes a universal evolutionary hierarchy of human parental goals. The primary goal is to encourage the survival and the health of a child. Secondary goals relate to developing the child into a self-supporting adult and instilling cultural beliefs and behavioral norms. Migration decisions of Maya parents are motivated by each of these goals. Economic and political conditions in Guatemala make it difficult for parents to achieve these goals for their children. The political economy of the United States offers real possibilities for success, and Maya parents seize upon these, just as other immigrants have done before them. In the United States infant mortality is low, and children are significantly larger and healthier than their counterparts in Guatemala. Furthermore, long-term economic prospects are considered substantially better, and social, religious, and other ideological beliefs can be pursued with less fear of condemnation and reprisal than in Guatemala.

Parental investment behaviors are a central part of the traditional Maya way of life. In the face of poverty, children are valued for 
their human capital. The authors' fieldwork experience in Guatemala reveals that, from an early age, Maya children begin running errands and taking care of younger siblings. Gradually, children and juveniles in agricultural areas assume responsibility for an ever-increasing variety of gathering, cultivation, and food processing tasks, and a similar process of apprenticeship and increasing productive responsibility occurs in Maya communities that produce textiles or other crafts. By adol escence Maya youth are working nearly as intensely, and productively, as adults. Parents and older siblings offer encouragement from an early age, and the children soon come to realize that their help is essential to an interdependent family effort (Loucky, 1988).

The skill acquisition and value formation inherent in this family-based system of education provides a built-in cultural intervention for a population at risk. For the refugees in the United States, the family-based system of education continues, with children still providing much labor for housecleaning, cooking, running errands, and care of younger siblings. Family education, however, must be supplemented with formal education in schools. Life in the United States requires new skills and ways of thinking. Maya children continue to play an essential role to the family's well-being by attending school and learning these new technical and cognitive skills. The children's school attendance is often the main sustained contact recently arrived families have with the institutions of their new society. Children daily cross the threshold between home and host society and play a valuable culturebroker role by translating and channeling English and other information from classroom to home.

Guatemalan parents in Indiantown and Los Angeles generally laud the benefits of school. However, there is consi derable variation in the degree of success the children achieve. Many children drop out of school by age 15, about the same age they would assume adult-like economic roles in Guatemala. Other Maya adolescents have completed high school and continue their education in trade school or college. These successes can usually be traced to families that offer a supportive environment for schooling. Examples of such families were presented above as brief case studies. Parents who invest in their children's education do so with both al truistic and sel fish motivation. Formal education will likely enhance the SEP status of the children, but it also provides a means of social and economic support for the parents when they are older and less able to work at physically demanding jobs.

\section{CONCLUSION}

The decisions of Maya parents to migrate to and within the United States are best viewed as rational responses to the biological, political, and social environments for child devel opment. From a bi osocial context, there are significant implications to the research that bi ol ogical anthropologists undertake. Human phenotypes, represented in this article as growth in height, weight, and body composition, are sensitive indicators of the physical, economic, and political environment. Much of the existing research on the factors influencing plasticity in human phenotypes focuses on the physical environment-for instance, the hypoxia of high altitude, the cold and heat of latitude extremes, or the nutritional stress experienced in traditional agricultural communities. Often, little can be done to alter the physical environment, and we ascribe variation in human physical and behavioral phenotypes to inevitable accommodations to them. However, all people live within social, economic, and political environments that also have powerful effects on human phenotypes. Much can be done to change the SEP environments, and biological anthropology has significant intellectual resources to contribute to peaceful change.

\section{ACKNOWLEDGMENTS}

This research was supported by the Timothy and $\mathrm{J}$ ean Morbach Research Fund of the University of Michigan-Dearborn and the Bureau for Faculty Research at Western Washington University. Sincere thanks to Sister Carol J ean, Sister Marie Celeste, A. Silvestre, and R. Parrish of Indiantown, Florida, and to J. Gaspar, M. Mendez, P. $\mathrm{J}$ imenez, and F. Peñalosa for assistance in Los Angeles, California. 


\section{LITERATURE CITED}

Adams RN (1970) Crucifixion by Power. Austin: University of Texas Press.

Alvarado WR (1995) El Tzolkin es Mas Que un Calendario. Guatemala City: Centro de Documentacion e Investigacion Maya.

Ashbranner B, and Conklin P (1986) Children of the Maya. New York: Dodd, Mead.

Boas F (1912) Changes in the bodily form of descendants of immigrants. American Anthropologist 14:530-563.

Boas F (1940) Race, Language and Culture. New York: Free Press.

Bogin B (1988a) Patterns of Human Growth. Cambridge: Cambridge University Press.

Bogin B (1988b) Rural-to-urban migration. In CGN Mascie-Taylor and GW Lasker (eds.): Biological Aspects of Human Migration. Cambridge: Cambridge University Press, pp. 90-129.

Bogin B (1989) Biological effects of urban migration on Hispanic populations. Am. J . Phys. Anthropol. 78:194 (abstract).

Bogin B (1990) The evolution of human childhood. Bioscience, 40:16-25.

Bogin B (1995) Plasticity in the growth of Mayan refugee children living in the United States. In CGN Mascie-Taylor and B Bogin (eds.): Human Variability and Plasticity. Cambridge: Cambridge University Press, pp. 46-74.

Bogin B, and MacVean RB (1984) Growth status of non-agrarian, semi-urban living Indians in Guatemala. Hum. Biol. 56:527-538.

Bogin B, Sullivan T, Hauspie R, and MacVean RB (1989) Longitudinal growth in height, weight, and bone age of Guatemala Ladino and Indian schoolchildren. Am J. Hum. Biol. 1:103-113.

Bogin B, Wall M, and MacVean RB (1992) Longitudinal analysis of adolescent growth of ladino and Mayan school children in Guatemala: Effects of environment and sex. Am. J. Phys. Anthropol. 89:447-457.

Bossert TJ, and Peralta E del Cid (1987) Guatemala Health Sector Assessment 1987 Update. Guatemala: USAID Mission in Guatemala.

Brown J L, and Pollitt E (1996) Malnutrition, poverty, and intellectual development. Sci. Am. 274(2):38-43.

Burns A (1989) The Maya of Florida. Migration World 27(3/ 4):20-26.

Burns A (1993) Maya in Exile. Philadelphia: Temple University Press.

Cameron N (1984) The Measurement of Human Growth. London: Croom Helm.

Crile GW, and Quiring DP (1939) A study of metabolism of the Maya-Quiché I ndian. J . Nutr. 18:369-374.

Downing TE (1979) Explaining migration in Mexico and elsewhere. In F Camara and R Van Kemper (eds.): Migration Across Frontiers: Mexico and the United States. Albany, NY: Institute for Mesoamerican Studies, State University of New York at Albany, pp. 159-167.

Diamond J (1992) A question of size. Discover 13(5): 70-77.

Fogel RW (1986) Physical growth as a measure of the economic wellbeing of populations: The eighteenth and nineteenth centuries. In F Falkner and J M Tanner (eds.): Human Growth, 2nd ed., Vol. 3. New York: Plenum, pp. 263-281.

Frisancho AR (1981) New norms of upper limb fat and muscle areas for the assessment of nutritional status. Am. J . Clin. Nutr. 34:2540-2545.

Frisancho AR (1990) Anthropometric Standards for the Assessment of Growth and Nutritional Status. Ann Arbor: University of Michigan Press.
Garn SM (1987) The secular trend in size and maturational timing and its implications for nutritional assessment. J . Nutr. 117:817-823.

Garn SM, Pesick SD, and Pilkington JJ (1984) The interaction between prenatal and socioeconomic effects on growth and development in childhood. In J Borms, R Hauspie, C Sand, C Susanne, and M Hebbelinck (eds.): Human Growth and Development. New York: Plenum, pp. 59-70.

Goff CW (1948) Anthropometry of a Mam-speaking group of Indians from Guatemala. Am. J . Phys. Anthropol. 6:429-448.

Goldstein MS (1943) Demographic and Bodily Changes in the Descendants of Mexican Immigrants. Austin: Institute of Latin American Studies.

Gurney TM, and J elliffe DB (1973) Arm anthropometry in nutritional assessment: Nomogram for the rapid calculation of muscle circumference and cross-sectional muscleand fat areas. Am. J . Clin. Nutr. 26:912915.

Hamill PV, J ohnson CL, Reed RB, and Roche AF (1977) NCHS growth curves for children. Vital Health Stat. 11:165.

Handy J (1984) Gift of the Devil: A History of Guatemala. Boston: South End Press.

J ackson J A (ed.) (1969) Migration. Cambridge: Cambridge University Press.

J ohnson CL, Fulwood R, Abraham S, and Bryner J D (1981) Basic data on anthropometric measurements and angular measurements of the hip and knee joints for sel ected age groups 1-74 years of age. Vital Health Stat. 11:219.

J ohnston FE, Low SM, Baessa $Y$ de, and MacVean RB (1985) Growth status of disadvantaged urban Guatemalan children of a resettled community. Am. J . Phys. Anthropol. 68:215-224.

Kohpahl G (1994) Where do I find the women? Research with undocumented Guatemala refugee women in L oS Angeles. In: Selected Papers on Refugee I ssues, III . J L MacDonald and A Zaharlick (eds.) Washington, DC: American Anthropology Association, pp. 153-168.

Komlos J (ed.) (1994) Stature, Living Standards, and Economic Development. Chicago: University of Chicago Press.

Lasker GW (1952) Environmental growth factors and selective migration. Hum. Biol. 24:262-289.

Lasker GW (1969) Human biological adaptability. Science 166:1480-1486.

Lasker GW (1995) The study of migrants as a strategy for understanding human biological plasticity. In CGN Mascie-Taylor and B Bogin (eds.): Human Variability and Plasticity. Cambridge: Cambridge University Press, pp. 110-114.

Leatherman TL, and Goodman AH (1996) Expanding the biocultural synthesis towards a biology of poverty. Am. J. Phys. Anthropol. 102:1-3.

LeVine $R$ (1977) Child rearing as a cultural adaptation. In PH Leiderman, S Tulkin, and A Rosenfeld (eds.): Culture and I nfancy: Variations in the Human Experience. New York: Academic Press, pp. 15-27.

Loucky J (1988) Children's Work and Family Survival in Highland Guatemala. PhD Dissertation. Ann Arbor: University Microfilms.

Loucky J (1993) Central American refugees: Learning new skills in the U.S.A. In MC Howard (ed.): Contemporary Anthropology, 4th ed. New York: HarperCollins, pp. 228-230.

Loucky J (1996) Maya Americans: The emergence of a transnational community. In N Hamilton and N Chinchilla (eds.): Central Americans in California. Los Angeles: Center for Multiethnic Studies and Transnational Studies, University of Southern California, pp. 30-34. 
Manz B (1988) Refugees of a Hidden War: The Aftermath of Counterinsurgency in Guatemala. Albany: State University of New York Press.

Martorell R (1989) Body size, adaptation, and function. Human Organization 48:15-20.

Martorell R, Yarbrough C, Lechtig A, Delgado $H$, and Klein RE (1976) Upper arm anthropometric indicators of nutritional status. Am. J. Clin. Nutr. 29:46-53.

Martorell R, Mendoza FS, and Castillo RO (1984) Genetic and environmental determinants of growth in Mexican-Americans. Pediatrics, 84:864-871.

Méndez J , and Behrhorst C (1963) The anthropometric characteristics of Indian and urban Guatemalans. Hum. Biol. 35:457-469.

Najjar MF, and Kuczmarski RJ (1989) Anthropometric data and the prevalence of overweight for Hispanics: 1982-84. Vital Health Stat. 11:239.

Orlove BS (1980) Ecological anthropology. Annual Review of Anthropology, 9:253-273.

Pelletier DL (1991) Relationships Between Child Anthropometry and Mortality in Developing Countries: I mplications for Policy, Programs, and Future Research. Monograph 12. Ithaca, NY: Cornell Food and Nutrition Program.

Pelto GH, and Pelto PJ (1989) Small but healthy? An anthropological perspective. Hum Organization 48: 11- 15.

Plattner S (1974) Wealth and growth among Mayan Indian peasants. Human E cology 2:75-87.

Ravenstein EG (1885) The laws of migration. J ournal Royal Statistical Society, 48:167-227.

Roberts DF (1985) Genetic and nutritional adaptation. In K Blaxter and J C Waterlow (eds.): Nutritional Adaptation in Man. London: J ohn Libby, pp. 45-60.

RocheAF (ed.) (1979) Secular Trends in Human Growth, Maturation, and Development. Monographs of the Society for Research in Child Development, 44, no. 179. Chicago: University of Chicago Press.

Schell LM (1986) Community health assessment through physical anthropology: Auxological epidemiology. Human Organization 45:321-327.

Seckler D (1980) Malnutrition: An intellectual odyssey Western J ournal of Agricultural Economics 5:219227.

Seckler D (1982) "Small but healthy": A basic hypothesis in the theory, measurement, and policy of malnutrition. In Sukhatme PV (ed.): Newer Concepts of Nutrition and Their Implication for Policy. Pune, India: Maharashta Association for the Cultivation of Science Research Institute, pp. 127-137.
Shapiro HL (1939) Migration and environment. Oxford: Oxford University Press.

Shattuck DC, and Benedict FG (1931) Further studies of basal metabolism of Maya Indians. Am. J. Physiol. 96:518-528.

Smith CA (1988) Destruction of the material bases for Indian culture: E conomic changes in Totonicapán. In Carmack RM (ed.): Harvest of Violence: The Maya Indians and the Guatemalan Crisis. Norman: University of Oklahoma Press, pp. 206-231.

Spurr GB (1983) Nutritional status and physical work capacity. Yearbook of Physical Anthropology 26:1-35.

Stearns SC (1992) The Evolution of Life Histories. Oxford: Oxford University Press.

Stebor A (1992) Infant development among Guatemalan refugee families in South Florida. Ph.D. Dissertation, University of Florida, Gainesville.

Steggerda M, and Benedict FG (1932) Metabolism in Yucatan: A study of the Maya Indian. Am. J . Physiol. 100:274-284.

Tanner J M (1981) A History of the Study of Human Growth. Cambridge: Cambridge University Press.

Tobias PV (1985) The negative secular trend. J . Hum. Evol. 14:347-356.

Tzian L (1994) Mayas y Ladinos en Cifras: El Caso de Guatemala. Guatemala City: Cholsamaj.

Ulijaszek SJ, and Strickland SS (1993) Nutritional Anthropology: Prospects and Perspectives. London: Smith-Gordon.

Van Wieringen J C (1986) Secular growth changes. In F Falkner and J M Tanner (eds.): Human Growth: A Comprehensive Treatise, 2nd ed., Vol. 3. New York: Plenum, pp. 307-331.

Warren KB (1989) The Symbolism of Subordination: Indian Identity in a Guatemalan Town, 2nd ed. Austin: University of Texas Press.

Waterlow J C, Buzina R, Keller W, Lane J M, Nichaman $M Z$, and Tanner J M (1977) The presentation and use of height and weight data for comparing the nutritional status of groups of children under the age of 10 years. Bull. World Health Organ. 55:489-498.

Watts ES, J ohnston FE, and Lasker GW (1975) Biosocial Interrelations in Population Adaptation. The Hague: Mouton.

Wellmeier N (1994) Rituals of resettlement: Identity and resistance among Maya refugees. In J L MacDonald and A Zaharlick (eds.): Selected Papers on Refugee Issues, III. Washington, DC: American Anthropology Association, pp. 9-28. 